\title{
Ultraviolet irradiation inactivates the waterborne infective stages of Myxobolus cerebralis: a treatment for hatchery water supplies
}

\author{
R. P. Hedrick ${ }^{1, *}$, T. S. McDowell ${ }^{1}$, G. D. Marty ${ }^{2}$, K. Mukkatira $^{1}$, D. B. Antonio ${ }^{1}$, \\ K. B. Andree ${ }^{1}$, Z. Bukhari ${ }^{3}$, T. Clancy ${ }^{3}$ \\ ${ }^{1}$ Department of Medicine and Epidemiology and ${ }^{2}$ Department of Anatomy, Physiology, and Cell Biology, School of \\ Veterinary Medicine, University of California, One Shields Avenue, Davis, California 95616, USA \\ ${ }^{3}$ Clancy Environmental Consultants, Inc., St. Albans, Vermont 05478, USA
}

\begin{abstract}
The effects of ultraviolet (UV) irradiation on the viability of the waterborne triactinomyxon stages of Myxobolus cerebralis were evaluated by vital staining and the infectivity for juvenile rainbow trout Oncorhynchus mykiss. A dose of $1300 \mathrm{~mW} \mathrm{~s} \mathrm{~cm}^{-2}$ was required to inactivate $100 \%$ of the triactinomyxons held under a static collimated beam of UV as determined by vital staining. Juvenile rainbow trout were protected from infections with $M$. cerebralis when exposed to 14000 or 1400 triactinomyxon spores per fish that had been treated with the collimating beam apparatus $\left(1300 \mathrm{~mW} \mathrm{~s} \mathrm{~cm}^{-2}\right)$. Among all fish receiving UV-treated triactinomyxons, none had clinical signs of whirling disease, or evidence of microscopic lesions or spores of $M$. cerebralis after 5 mo at water temperatures of $15^{\circ} \mathrm{C}$. In contrast, $100 \%$ of the fish receiving the higher dose of untreated triactinomyxons developed clinical signs of whirling disease and both microscopic signs of infection and spores were detected in all of the high and low dose trout receiving untreated triactinomyxon exposures. Two additional trials evaluated the Cryptosporidium Inactivation Device (CID) for its ability to treat flow-through $15^{\circ} \mathrm{C}$ well water to which triactinomyxons were added over a 2 wk period. CID treatments of a cumulative dose exceeding 64000 triactinomyxons per fish protected juvenile rainbow from infections with $M$. cerebralis. Rainbow trout controls receiving the same number of untreated triactinomyxons developed both microscopic lesions and cranial spore concentrations up to $10^{4.6}$ per $1 / 2$ head, although no signs of clinical whirling disease were observed. UV $\left(126 \mathrm{~mW} \mathrm{~s} \mathrm{~cm}^{-2}\right.$, collimated beam apparatus) was also effective in killing Flavobacterium psychrophilum, the agent causing salmonid bacterial coldwater disease, as demonstrated by the inability of bacterial cells to grow on artificial media following UV treatment.
\end{abstract}

KEY WORDS: Whirling disease $\cdot$ Flavobacterium psychrophilum · Ultraviolet · Disease control

\section{INTRODUCTION}

Whirling disease among salmonid fish is caused by the myxozoan parasite Myxobolus cerebralis (Hofer 1908). The disease, once thought to be problematic only among hatchery-reared salmonids (Halliday 1976, Hoffman 1990), has now been identified as a major cause of declines among certain wild trout

*E-mail: rphedrick@ucdavis.edu populations in the intermountain west of the USA (Nehring \& Walker 1996, Vincent 1996). The disease has been effectively managed in hatchery-reared salmonids by preventing or reducing the exposure of young susceptible fish to the infectious stages or triactinomyxons as released from infected oligochaetes (Hoffman 1990). This has been accomplished by rearing young fish in well water to avoid exposures to the parasite until fish are older and more resistant, or by modifying pond designs to minimize habitat for the oligochaete host (Schaperclaus 1986, Wolf 1986). 
While clinical disease manifestations may be controlled by these measures, fish are infected and the parasite develops to form spores in the skeletal elements. The stocking of subclinically infected fish is one principal method responsible for the spread of whirling disease (Hoffman 1970, Modin 1998).

The studies of Wolf \& Markiw (1984) demonstrated the 2-host life cycle for the parasite and identified the previously unknown waterborne infectious stages of Myxobolus cerebralis: the triactinomyxons. The spore stages produced in the fish are extremely resistant to physical and chemical inactivation (El-Matbouli et al. 1992). In contrast, the triactinomyxon stages released into the water from infected oligochaetes are shorter lived and more susceptible to inactivation (Markiw 1992a). Removing or inactivating these waterborne infectious stages is viewed as an essential approach to controlling infections with $M$. cerebralis among salmonids when surface waters must be utilized for hatchery rearing. Hoffman $(1974,1975)$ demonstrated that ultraviolet light (UV) treatments were effective in protecting rainbow trout from whirling disease even though the waterborne infectious stages were at that time unknown. Hoffman $(1974,1975)$ found UV treatments at doses ranging from 18 to $112 \mathrm{~mW} \mathrm{~s} \mathrm{~cm}^{-2}$ provided partial to complete protection from $M$. cerebralis infections. These initial studies demonstrated the potential of UV treatments but did not establish minimum lethal doses required to inactivate the triactinomyxon form of $M$. cerebralis. In more recent years, sophisticated and much more powerful systems for treatment of water with UV (for municipal water supplies) have been developed (Campbell et al. 1995, Clancy et al. 1998, Bukhari et al. 1999). The Cryptosporidium Inactivation Device (CID) technology is one example of these newer approaches to the use of disinfection of water using UV light (Clancy et al. 1998). This device uses a combination of UV and nominal $2 \mu \mathrm{m}$ sintered stainless steel screens for effective trapping and inactivation of the human pathogen Cryptosporidium in municipal water supplies. In this study we describe the use of a collimating beam apparatus to determine the dose response curves for the triactinomyxon stages of $M$. cerebralis as evaluated by vital staining and infectivity for rainbow trout Oncorhynchus mykiss. In addition, we examined the dose response of Flavobacterium psychrophilum, the agent causing salmonid bacterial coldwater disease, to UV irradiation (Bernardet et al. 1996). We then tested the efficacy of UV treatments as provided by the CID to inactivate triactinomyxons introduced into a flowthrough system to aquaria containing rainbow trout. The results of these studies and the application of these approaches to eliminate $M$. cerebralis from hatchery water supplies are described here.

\section{METHODS}

Laboratory propagation of parasite stages. The triactinomyxons of Myxobolus cerebralis were propagated in the laboratory from known susceptible oligochaete populations infected with spores extracted from rainbow trout Oncorhynchus mykiss tissues by the plankton centrifuge procedure as described by Andree et al. (1998). Triactinomyxons from infected oligochaete populations were harvested every 2 to $3 \mathrm{~d}$ as required for evaluating the efficacy of UV light treatments in destroying the infectivity of the triactinomyxons for fish. Two UV inactivation procedures were employed, the first utilized a collimating beam apparatus for establishing dose response curves by vital staining and destruction of infectivity for rainbow trout (static UV treatments). The second procedure involved continuous treatments of large water volumes with the CID, a unit designed to treat municipal water supplies (Clancy et al. 1998). During flow-through trials with the CID, triactinomyxons were periodically added to the water supply before entering the CID; treated water was dispensed to tanks containing young rainbow trout.

UV dose response curves-collimating beam. A collimating beam apparatus (kindly supplied by Safe Water Solutions L.L.C., Scottsdale, Arizona) with 4 identical beams of UV light from 1 light tube was used to direct UV light onto 4 petri dishes mounted on insulated magnetic stir plates (Bukhari et al. 1999). The intensity of the UV irradiation on bisecting $x$ - and $y$ axes of the dishes was measured with a radiometer and sensor (Bukhari et al. 1999). The measured values were used to calculate an average irradiance over the surface of the dish.

The effects of UV exposure on triactinomyxons suspended in $20 \mathrm{ml}$ of water in each petri dish under 3 of the replicate UV beams was compared with 2 control dishes shielded from the radiation. The solutions were mixed gently throughout the treatment with magnetic stir bars. In the initial dose response experiments $0.1 \mathrm{ml}$ aliquots were removed from each dish at selected time points for later analysis by vital staining. The appropriate dosage for complete inactivation of the triactinomyxons was then determined. Subsequently, larger numbers of parasites were irradiated and tested for their ability to infect young rainbow trout.

Vital staining of triactinomyxons. An adaptation of the vital stain originally used for triactinomyxons of Myxobolus cerebralis by Markiw (1992b) and as described by Wagner (1998) was used to determine potential viability of the parasite after exposure to UV irradiation. A $100 \mu \mathrm{l}$ aliquot from the parasite suspension was mixed on a microscope slide with $50 \mu$ l of a 
$52 \mathrm{mg} \mathrm{l}^{-1}$ propidium iodide solution and $50 \mu \mathrm{l}$ of fluorescein diacetate $\left(100 \mu \mathrm{l}\right.$ of $5 \mathrm{mg} \mathrm{ml}^{-1}$ stock solution added to $8.3 \mathrm{ml}$ water). A coverslip was added and the slide was held at least $45 \mathrm{~min}$ at $4^{\circ} \mathrm{C}$ before examination with a microscope equipped with the proper excitation and barrier filters. Under these conditions viable sporoplasm cells in the triactinomyxons stained green while those that were inactivated stained red.

Effects of static UV treatments on infectivity for trout. Triactinomyxons for the fish infectivity study were aliquoted to 8 petri dishes: 4 dishes with $1.4 \times 10^{6}$ and 4 with $1.40 \times 10^{5}$ triactinomyxons provided a low (1400 per fish) and high (14 000 per fish) dose exposure of rainbow trout. Two dishes from each group were treated with UV for the equivalent of $1300 \mathrm{~mW} \mathrm{~s} \mathrm{~cm}^{-2}$ at $20^{\circ} \mathrm{C}$. The irradiance under the beam was $135 \mu \mathrm{W}$ $\mathrm{cm}^{-2}$; therefore, approximately $3 \mathrm{~h}$ was required to achieve the needed dose. Two dishes from each group were held under the same conditions but did not receive UV treatment (Low and High). Groups of 40 rainbow trout $(0.2 \mathrm{~g})$ were then exposed to the contents of each petri dish representing the 4 treatment groups in $15^{\circ} \mathrm{C}$ well water. An additional 2 groups of 40 fish received no exposures to triactinomxyons (unexposed control). The fish were then transferred to 201 aquaria receiving $15^{\circ} \mathrm{C}$ well water at a rate of $31 \mathrm{~min}^{-1}$. Details on the exposure protocols and fish maintenance are described by Hedrick et al. (1999a). After 5 wk, 5 fish from each unexposed group and each group receiving high dose triactinomyxon exposures with or without UV treatments were removed and examined by PCR for the presence of Myxobolus cerebralis infection (Andree et al. 1998). At 5 mo post-exposure the experiment was terminated. Ten fish from each tank were examined individually for spore concentrations in cranial cartilage and microscopic lesions in stained tissue sections associated with $M$. cerebralis (Thoesen 1994) as described by Hedrick et al. (1999b). Remaining fish in all groups exposed to UV-treated parasites were analyzed as 5 fish pools for the presence or absence of the spores in cranial cartilage.

Effects of CID UV treatments on infectivity for trout. The CID unit was installed directly into the Fish Disease Laboratory at the University of California Davis such that all water delivered to six $130 \mathrm{l}$ tanks received treatment prior to contacting the fish. The CID unit irradiates water that flows through its $2 \mu \mathrm{m}$ filters, and particulates trapped on the filter are treated with highenergy UV irradiation. The filtration and irradiation cycles between 2 chambers, and filters are back flushed at the end of each cycle to maintain flow rates. During triactinomyxon trials, the flow of $15^{\circ} \mathrm{C}$ well water through the machine was $18 \mathrm{l} \mathrm{min}^{-1}$, with $3 \mathrm{l}$ $\min ^{-1}$ flowing into each of the 6 test aquaria. At all other times the flow through the machine was $131 \mathrm{l}$ $\min ^{-1}$, with flow in excess of the $181 \mathrm{~min}^{-1}$ bypassing the fish tanks into a recirculating loop with a $650 \mathrm{l}$ circular holding tank.

To introduce parasites into the treatment system, tractinomyxons were suspended in $4 \mathrm{l}$ of water and metered into the intake pipe of the CID with a pump over a period of approximately $12 \mathrm{~min}$. This time frame overlapped the cycle between the 2 chambers of the filtration-irradiation units to ensure that parasites were flowing through the complete range of the machine's function. The UV dosage on the CID was set at $4000 \mathrm{~mW} \mathrm{~s} \mathrm{~cm}^{-2}$ per chamber, a significant excess over the $1300 \mathrm{~mW} \mathrm{~s} \mathrm{~cm}^{-2}$ actually required for inactivation of the triactinomyxons. The design of the CID ensures that organisms trapped temporarily on the screens before passing through the machine receive a minimum of $4000 \mathrm{~mW} \mathrm{~s} \mathrm{~cm}^{-2}$ and a maximum of $8000 \mathrm{mWs}$ $\mathrm{cm}^{-2}$.

For testing of the CID with parasite challenge studies, 13 rainbow trout $(2.4 \mathrm{~g})$ were placed in 21 of water in each of the 6 tanks supplied with water treated by the CID. Water supply to the tanks was arrested for 5 min after the addition of the parasites to the CID to provide time for passage of the parasites through the machine; then water flow to each tank was resumed at a rate of $31 \mathrm{~min}^{-1}$. Parasites were introduced into the CID over a 12 min period. A period of 19 min was required to bring the volume to capacity in the $130 \mathrm{l}$ tanks. Water flow into the tanks was stopped when full, and tanks were held with aeration but without water flow for $14 \mathrm{~h}$ to maximize contact between parasites in the aquaria. Flows were resumed the next day, and fish were maintained as previously described. Untreated triactinomyxon control exposures were designed to mimic conditions of the CID treated exposures. Thirteen fish were placed in $2 \mathrm{l}$ of water in similar tanks, with water inflow set at $31 \mathrm{~min}^{-1}$. An amount of parasites equal to $\frac{1}{6}$ of that injected into the CID unit was added to each tank. Water flow was stopped when tanks were full. Tanks were held static overnight, with flows returned to $31 \mathrm{~min}^{-1}$ to each tank the next day. A total of 64200 triactinomyxons per fish was added through a series of 4 exposures over a $2 \mathrm{wk}$ period to fish in both the CID and untreated water groups. A group of fish held under the same conditions but receiving only well water and no parasites served as unexposed controls. The well water temperature throughout the trial was maintained at $15^{\circ} \mathrm{C}$. The study was conducted in the winter such that water temperatures would not increase or decrease significantly during static water periods of exposure. The fish were maintained as described previously (Andree et al. 1998). Five fish from replicate unexposed, CID exposed, and exposed untreated aquaria were examined by PCR analysis at $5 \mathrm{wk}$ post-exposure (Andree et al. 
1998). In addition, 5 fish from replicate unexposed, exposed untreated aquaria and 10 fish from each CID exposed aquaria were examined for cranial spore concentrations and microscopic lesions at 5 mo postexposure. Two separate trials (Trials 1 and 2) were conducted following this procedure with the only difference that fish in Trial 1 received a cumulative dose over a period of 2 wk of 7539 triactinomyxons compared to 64200 triactinomyxons per fish in Trial 2.

UV dose response curves for Flavobacterium psychrophilum. An additional study conducted with the UV collimating beam apparatus examined the inactivation of the bacterial pathogen Flavobacterium psychrophilum. The bacterium was grown in broth (Anacker \& Ordal 1955) at $15^{\circ} \mathrm{C}$ for $72 \mathrm{~h}$. Broth cultures were then distributed into 3 aliquots of $20 \mathrm{ml}$ in sterile petri dishes. Two replicates were exposed to UV irradiation $\left(140 \mu \mathrm{W} \mathrm{cm}{ }^{-2}\right)$ and 1 dish was not irradiated (control). Aliqouts of $0.5 \mathrm{ml}$ were removed at selected exposure times from all 3 plates, suspended in Anacker and Ordal broth for serial dilutions and spread onto tryptone yeast extract (TYES) agar for enumeration of viable cells. Colonies were counted after $7 \mathrm{~d}$ incubation at $15^{\circ} \mathrm{C}$.

\section{RESULTS}

\section{UV dose response curves - vital staining}

A cumulative dose of $1300 \mathrm{~mW} \mathrm{~s} \mathrm{~cm}^{-2}$ was required to inactivate the triactinomyxons as suspended in well water under the conditions tested (Fig. 1). The sporo-

Table 1. Effects of static ultraviolet light treatments with the collimating beam apparatus on the infectivity of 2 concentrations of triactinomyxons (High and Low) for juvenile rainbow trout. nd: no spores detected

\begin{tabular}{|c|c|c|c|c|c|}
\hline \multirow[b]{3}{*}{ Parasite exposure dose ${ }^{a}:$} & \multicolumn{4}{|c|}{ Triactinomyxon exposure } & \multirow[b]{3}{*}{ None } \\
\hline & \multicolumn{2}{|c|}{ UV-treated } & \multicolumn{2}{|c|}{ No treatment } & \\
\hline & High & Low & High & Low & \\
\hline Presence of clinical signs ${ }^{\mathrm{b}}$ & $0 / 64$ & $0 / 69$ & $54 / 54$ & $8 / 62$ & $0 / 66$ \\
\hline Preva & $0 / 20$ & $0 / 20$ & $20 / 20$ & $20 / 20$ & $0 / 20$ \\
\hline Mean lesion score ${ }^{\mathrm{d}}$ & 0 & 0 & 3.0 & 2. & 0 \\
\hline Mean spore count ${ }^{\mathrm{e}}$ & nd & nd & $10^{5.6}$ & $10^{4.6}$ & 0 \\
\hline \multicolumn{6}{|c|}{$\begin{array}{l}\text { aDose of triactinomyxon stages of Myxobolus cerebralis per fish used in the } \\
\text { exposures for High was } 14000 \text { and Low } 1400 \text { triactinomyxons per fish }\end{array}$} \\
\hline \multicolumn{6}{|c|}{ bresence of black tail or whirling swimming at 2 mo post-exposure } \\
\hline \multicolumn{6}{|c|}{$\begin{array}{l}\text { 'Infection with } M \text {. cerebralis was determined by presence of spores in the } \\
\text { pepsin trypsin digestion of } 1 / 2 \text { of the head of } 20 \text { individual fish ( } 10 \text { from each } \\
\text { of } 2 \text { replicate groups per treatment) at } 5 \text { mo post-exposure }\end{array}$} \\
\hline \multicolumn{6}{|c|}{$\begin{array}{l}\text { d Microscopic lesions were scored on a scale of none }(0) \text { to severe (5) among } \\
10 \text { fish in the high exposure group at } 5 \text { mo post-exposure }\end{array}$} \\
\hline \multicolumn{6}{|c|}{$\begin{array}{l}\text { eMean concentration of spores (per } 1 / 2 \text { head) among infected fish in each } \\
\text { group at } 5 \text { mo post-exposure }\end{array}$} \\
\hline
\end{tabular}

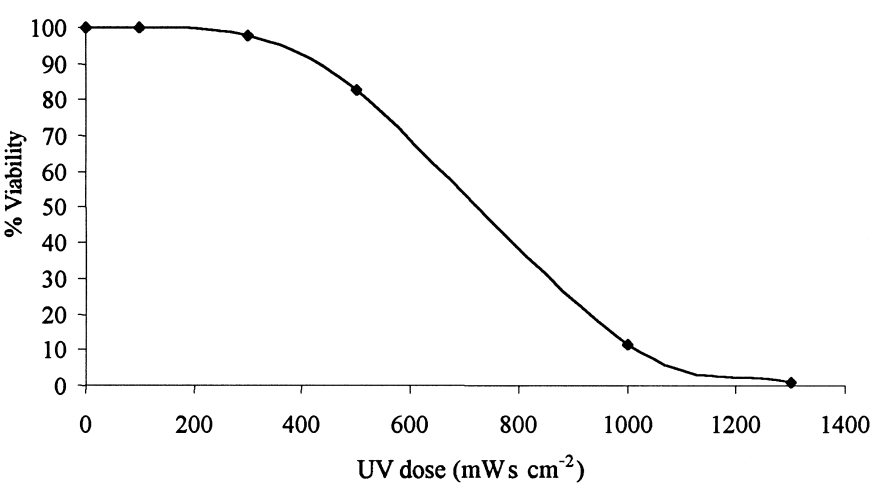

Fig. 1. Effects of cumulative dose of ultraviolet light on the viability of triactinomyxon stages of Myxobolus cerebralis as determined by vital staining

plasm cells in the apical end of the triactinomyxon all stained red after treatment at this dosage, suggesting that these cells were no longer viable. In contrast, $57 \%$ of the untreated triactinomyxons held under the same conditions contained sporoplasm cells all of which stained green, suggesting they were viable. Using the cumulative dose of $1300 \mathrm{~mW} \mathrm{sm}^{-2}$ as an estimate, trials with larger numbers of triactinomyxons were conducted for the subsequent fish exposure studies.

\section{Effect of static (UV collimating beam) treatments on infectivity for trout}

At 5 wk post-exposure and prior to the onset of clinical signs, all 10 fish receiving the high dose of untreated triactinomyxons were positive, while those fish receiving the UVtreated triactinomyxons were all negative (PCR test). In addition, 10 unexposed, untreated control fish were also negative. Clinical signs including black tail and whirling swimming first became evident at $6 \mathrm{wk}$ following exposure to triactinomyxons in the high dose not treated with $\mathrm{UV}_{i}$ by 2 mo $100 \%$ of the fish in the high dose group and $13 \%$ in the low dose group displayed clinical signs (Table 1). No clinical signs were observed among fish in any groups receiving UVtreated triactinomyxons. At 5 mo postexposure, none of the trout receiving either the high or low dose triactinomyxons treated with UV had microscopic lesions or spores (Table 1). In contrast, $100 \%$ of the fish exposed to triactinomyxons not treated with UV 
had microscopic lesions in the cranium and gills, with mean overall severity scores of 3.0 (high triactinomyxon exposure) and 2.2 (low triactinomyxon exposure). Mean spore concentrations for fish in the high and low group exposure to untreated triactinomyxons were $10^{5.6}$ and $10^{4.6}$ per $\frac{1}{2}$ head, respectively (Table 1 ).

\section{Efficacy of CID UV treatments on infectivity for trout}

Two trials conducted with the CID provided similar results demonstrating the efficacy of this water treatment in eliminating infectivity of the triactinomyxon stage of Myxobolus cerebralis from water supplied to juvenile trout. At $5 \mathrm{wk}$ post-exposure, prevalence of PCR-positive fish in groups receiving untreated triactinomyxons was less in Trial $1(1 / 6)$ than in Trial 2 (6/6). In both trials fish receiving CID-treated triactinomyxons were PCR-negative (0/6). In addition, 6 unexposed, untreated control fish in both Trials 1 and 2 were also PCR-negative. But for 1 fish in the untreated triactinomyxon-exposed groups in Trial 2, no clinical signs were observed during the course of either trial. In both trials at 5 mo post-exposure, none of the 20 fish sampled from the CID-treated groups had microscopic lesions or spores (Table 2). In contrast, $100 \%$ of the fish receiving untreated triactinomyxons contained microscopic lesions in the cranium and gills, with a mean score of 2.4 in Trial 2. No microscopic pathological examinations were conducted in Trial 1. The mean spore concentrations per $1 / 2$ head for the untreated triactinomyxon group was greater in Trial 2 than in Trial 1.

Table 2. Efficacy of the Cryptosporidium Inactivation Device (CID) in protecting juvenile rainbow from exposures to triactinomyxons of Myxobolus cerebralis. nd: no spores detected

\begin{tabular}{|c|c|c|c|c|c|c|}
\hline & \multicolumn{4}{|c|}{ Triactinomyxon-exposed ${ }^{\mathrm{a}}$} & \multirow{2}{*}{\multicolumn{2}{|c|}{$\begin{array}{l}\text { Unexposed } \\
\text { controls }\end{array}$}} \\
\hline & \multicolumn{2}{|c|}{ CID-treated } & \multicolumn{2}{|c|}{ No treatment } & & \\
\hline & Trial 1 & Trial 2 & Trial 1 & Trial 2 & Trial 1 & Trial 2 \\
\hline Prevalence of infection ${ }^{\mathrm{b}}$ & $0 / 20$ & $0 / 20$ & $18 / 20$ & $20 / 20$ & $0 / 20$ & $0 / 20$ \\
\hline Mean lesion score ${ }^{c}$ & - & 0 & - & 2.4 & $0 / 20$ & $0 / 20$ \\
\hline Mean spore count ${ }^{\mathrm{d}}$ & nd & nd & $10^{4.4}$ & $10^{4.6}$ & nd & nd \\
\hline \multicolumn{7}{|c|}{$\begin{array}{l}\text { aFish were exposed to a cumulative dose of } 7539 \text { (Trial 1) or } 64200 \text { (Trial 2) } \\
\text { triactinomyxons per fish over a } 2 \text { wk period }\end{array}$} \\
\hline \multicolumn{7}{|c|}{$\begin{array}{l}{ }^{\mathrm{b}} \text { Infection with } M \text {. cerebralis was determined by presence of spores in the } \\
\text { pepsin trypsin digestion of } 1 / 2 \text { of the head of } 20 \text { individual fish ( } 10 \text { from each } \\
\text { of } 2 \text { replicate groups per treatment) at } 5 \text { mo post-exposure }\end{array}$} \\
\hline \multicolumn{7}{|c|}{$\begin{array}{l}{ }^{\mathrm{c}} \text { Microscopic lesions were scored on a scale of none }(0) \text { to severe }(5) \text { among } \\
10 \text { fish in the high exposure group at } 5 \text { mo for Trial } 2 \text { only }\end{array}$} \\
\hline \multicolumn{7}{|c|}{$\begin{array}{l}{ }^{\mathrm{d}} \text { Mean concentration of spores among infected fish in each group at } 5 \mathrm{mo} \\
\text { post-exposure }\end{array}$} \\
\hline
\end{tabular}

Table 3. Effects of static ultraviolet light treatments with the collimating beam apparatus on the viability of Flavobacterium psychrophilum. The numbers of viable bacteria are expressed as colony forming units $\mathrm{ml}^{-1}$

\begin{tabular}{|lccc|}
\hline \multirow{2}{*}{$\begin{array}{c}\text { Time } \\
(\mathrm{min})\end{array}$} & $\begin{array}{c}\text { Untreated } \\
\text { control }\end{array}$ & \multicolumn{2}{c|}{$\begin{array}{c}\text { Treated with UV } \\
\text { irradiation }\end{array}$} \\
& & Replicate 1 & Replicate 2 \\
\hline 0 & $2.2 \times 10^{5}$ & $1.0 \times 10^{5}$ & $6.0 \times 10^{4}$ \\
5 & $2.6 \times 10^{5}$ & $1.0 \times 10^{5}$ & $5.0 \times 10^{4}$ \\
15 & $2.3 \times 10^{5}$ & 0 & 0 \\
30 & $2.2 \times 10^{5}$ & 0 & 0 \\
\hline
\end{tabular}

\section{UV dose response curves for Flavobacterium psychrophilum}

Treatments of suspensions of Flavobacterium psychrophilum with UV irradiation were ineffective at doses of $42 \mathrm{~mW} \mathrm{~s} \mathrm{~cm}^{-2}$ (Table 3). However, at doses of 126 or $252 \mathrm{~mW} \mathrm{~s} \mathrm{~cm}^{-2}$ bacterial cells were killed by the treatment (Table 3).

\section{DISCUSSION}

UV irradiation was effective in destroying the viability of the triactinomyxon stages of Myxobolus cerebralis as determined by both vital staining and elimination of infectivity for young rainbow trout. UV treatments were highly effective whether administered in small volumes with a low pressure collimating beam apparatus, or in larger volumes with higher intensity radiation in a flow-through device (CID) designed for water supplies. These results demonstrated the feasibility of UV irradiation, even at larger scales needed for hatchery water supplies, to prevent infections of hatchery reared trout with $M$. cerebralis. In addition, the UV dose effective against $M$. cerebralis also inactivated the bacterium Flavobacterium psychrophilum, the cause of salmonid bacterial coldwater disease.

UV irradiation has been most commonly used to eliminate or reduce pathogens in closed recirculating fish rearing units but also in larger scale fish production units using single-pass water (Hoffman 1974). The principal mode of action for UV irradiation, particularly that in the 220 to $300 \mathrm{~nm}$ wavelengths, is the formation of pyrimidine dimers in the target cell DNA 
(Schechmeister 1991). Among the many stages of Myxobolus cerebralis, the most susceptible form to both chemical and physical destruction is the triactinomyxon, the form released into the water from the oligochaete host (Markiw 1992b). This is the form present in the water that effectively attaches to the epidermis of the fish and then proceeds to invade through the skin, migrating to the nerves, and finally to the cartilage (Markiw 1989, El-Matbouli et al. 1995). This stage of the parasite is large (up to $180 \mu \mathrm{m}$ between valve tips) and possesses relatively thin valves as protection for the approximately 64 sporoplasm cells that are packaged for delivery into the fish epidermis (ElMatbouli et al. 1999). Although unknown at the time, the first trials with UV with $M$. cerebralis by Hoffman $(1974,1975)$ were targeting these triactinomyxon stages. Hoffman $(1974,1975)$ recommended treatments of $35.0 \mathrm{~mW} \mathrm{~s} \mathrm{~cm}^{-2}$ for the elimination of $M$. cerebralis infectivity from water supplies. He found that treatments of 18.0 to $27.7 \mathrm{~mW} \mathrm{~s} \mathrm{~cm}^{-2}$ gave less consistent results, protecting fish from clinical disease but not all fish from infections.

In our trials with the collimated beam apparatus, levels of $1300 \mathrm{~mW} \mathrm{sm}^{-2}$ were required to inactivate triactinomyxons as judged by the lack of viable staining of all of the sporoplasm cells in all of the triactinomyxons. This dosage is probably in excess of that required as it may not be necessary to inactivate all the sporoplasm cells to render the triactinomyxon noninfectious. This in part may explain why much lower doses were effective in the trials by Hofmann $(1974,1975)$.

Treatments of larger volumes of water in hatchery water supplies, particularly during early fish rearing, is viewed as one possible means to aid in the control of whirling disease. While the flow rates examined in our study were below the capacity of the apparatus, the CID effectively eliminated infectivity of triactinomyxons as administered in repeated dosages over a 2 wk period in 2 separate trials. In the CID, water passing through the $2 \mu \mathrm{m}$ screen receives a dose of $4000 \mathrm{mWs}$ $\mathrm{cm}^{-2}$ and materials temporarily trapped on the filter can be treated at even higher doses up to $8000 \mathrm{~mW} \mathrm{~s}$ $\mathrm{cm}^{-2}$. These doses of UV irradiation are well above the $1300 \mathrm{mWs} \mathrm{cm}^{-2}$ determined from the static trials to eliminate all infectivity due to Myxobolus cerebralis. We presume, but did not test, that the physical forces during the temporary filtration experienced by triactinomyxons entering the CID could contribute to shearing of the parasite that might also greatly reduce infectivity. We have found that although triactinomyxons are large when fully extended (up to $180 \mu \mathrm{m}$ ) they can fold upon themselves and effectively pass through screen sizes of $20 \mu \mathrm{m}$ (authors' unpubl. data). However, triactinomyxons entering a $2 \mu \mathrm{m}$ screen under pressure would be retained and only sporoplasm stages, which presumably are noninfectious once released from the surrounding membrane, would pass the screen (ElMatbouli et al. 1999). Larger models of the CIDs are available with capabilities to treat up to $33441 \mathrm{~min}^{-1}$, and these could be used for early rearing of salmonids to prevent serious infections with $M$. cerebralis. At one local hatchery, we estimated that 2 larger CID would be sufficient to rear 200000 steelhead trout through the first 4 mo after hatching.

UV irradiation was also effective in destroying the salmonid bacterial pathogen Flavobacterium psychrophilum, a pathogen often occurring in the same hatcheries as whirling disease. Furthermore, this bacterium is prevalent among salmonid fish throughout the world and a major cause of losses among hatchery-reared rainbow trout (Bernardet et al. 1996). The bacterium is transmitted through the water column from fish to fish and presumably with eggs from infected adult fish (Brown et al. 1997). The bacterium as shed into the water would pass the $2 \mu \mathrm{m}$ screen in the CID but the $4000 \mathrm{~mW} \mathrm{~s} \mathrm{~cm}^{-2}$ dose experienced as it passed the filter is well in excess of the $126 \mathrm{~mW} \mathrm{~s} \mathrm{~cm}^{-2}$ dose shown to inactivate over $10^{5}$ colony forming units of the bacterium in our trials (Table 3 ).

Certain mechanisms for the transmission of whirling disease remain unknown, but stocking or transfer of live infected fish to new locations is clearly one known mode (Modin 1998). When the suitable oligochaete and fish hosts and environment are present, whirling disease can thrive. If these conditions are not met, the disease may fail to be established or remain at a low level that in part may explain the differential impacts of whirling disease in the intermountain west compared to other eastern and western states (Hedrick et al. 1998). Groundwater should be used whenever possible for hatchery-rearing of salmonids in whirling disease enzootic waters (Hoffman 1990), but when this is not possible, treatment of the incoming surface water with UV is a feasible alternative to prevent infection with Myxobolus cerebralis. Our controlled laboratory trials and those of Hoffman $(1974,1975)$ demonstrate that UV irradiation, particularly when delivered by newly designed and more efficient apparatuses, should be seriously considered for hatchery programs aimed at stocking fish when surface waters contain the infectious stages of $M$. cerebralis.

Acknowledgements. Funding for this research came from the Colorado Division of Wildlife and Safe Water Solutions L.L.C. Contributors to this work included Mr Mark Sampson of Water Control Corporation and Mr Chuck Reading of Safe Water Solutions L.L.C. and Clancy Environmental Consultants Inc. 


\section{LITERATURE CITED}

Anacker RL, Ordal EJ (1955) Study of a bacteriophage infecting myxobacterium Chondrococcus columnaris. J Bacteriol 70:738-741

Andree KB, MacConnell E, Hedrick RP (1998) A nested polymerase chain reaction for the detection of genomic DNA of Myxobolus cerebralis in rainbow trout Oncorhynchus mykiss. Dis Aquat Org 34:145-154

Bernardet JF, Segers P, Vancanneyt M, Berthe F, Kersters K, Vandamme P (1996) Cutting a Gordian knot: emended classification and description of the genus Flavobacterium, emended description of the family Flavobacteriaceae, and proposal of Flavobacterium hydatis nom. nov (basonym, Cytophaga aquatilis Strohl and Tait 1978). J Syst Bacteriol 46:128-148

Brown LL, Cox WT, Levine RP (1997) Evidence that the causal agent of bacterial coldwater disease Flavobacterium psychrophilum is transmitted within salmonid eggs. Dis Aquat Org 29:213-218

Bukhari Z, Hargy TM, Bolton JR, Dussert B, Clancy JL (1999) Inactivation of Cryptosporidium parvum oocysts using medium-pressure ultraviolet light. J Am Water Works Assoc 91:86-94

Campbell AT, Robertson LJ, Snowball MR, Smith HV (1995) Inactivation of oocysts of Cryptosporidium parvum by ultraviolet irradiation. Water Res 29:2583-2586

Clancy JL, Hargy TM, Marshall MM, Dyksen JE (1998) Inactivation of Cryptosporidium parvum oocysts in water using ultraviolet light. J Am Water Works Assoc 90: 92-102

El-Matbouli M, Fischer-Scherl T, Hoffman RW (1992) Present knowledge of the life cycle, taxonomy, pathology, and therapy of some Myxosporea spp. important for freshwater fish. Annu Rev Fish Dis 3:367-402

El-Matbouli M, Hoffmann RW, Mandok C (1995) Light and electron microscopic observations on the route of the triactinomyxon-sporoplasm of Myxobolus cerebralis from epidermis into rainbow trout (Oncorhynchus mykiss) cartilage. J Fish Biol 46:919-935

El-Matbouli M, Hoffmann RW, Shoel H, McDowell TS, Hedrick RP (1999) Whirling disease: host specificity and interaction between the actinosporean stage of Myxobolus cerebralis and rainbow trout (Oncorhynchus mykiss) cartilage. Dis Aquat Org 35:1-12

Halliday MM (1976) The biology of Myxosoma cerebralis; the causative agent of whirling disease of salmonids. J Fish Biol 9:339-357

Hedrick RP, El-Matbouli M, Adkison MA, MacConnell E (1998) Whirling disease: re-emergence among wild trout. Immunol Rev 166:365-376

Hedrick RP, McDowell TS, Mukkatira K, Georgiadis MP, MacConnell M (1999a) Susceptibility of selected inland salmonids to experimentally-induced infections with Myxobolus cerebralis the causative agent of whirling disease. J Aquat Anim Health 11:330-339

Editorial responsibility: Wolfgang Körting,

Hannover, Germany
Hedrick RP, McDowell TS, Gay M, Marty GD, Georgiadis MP MacConnell M (1999b) Comparative susceptibility of rainbow trout Oncorhynchus mykiss and brown trout Salmo trutta to Myxobolus cerebralis, the cause of salmonid whirling disease. Dis Aquat Org 37:173-183

Hofer B (1903) Über die Drehkrankheit der Regenbogenforelle. Allg Fisch-Ztg Jahrg XXVIII (1):7-8

Hoffman GL (1970) Intercontinental and transcontinental dissemination and transfaunation of fish parasites with emphasis on whirling disease (Myxosoma cerebralis) In: Snieszko SF (ed) A symposium on diseases of fishes and shellfishes. Am Fish Soc, Washington, DC, p 69-81

Hoffman GL (1974) Disinfection of contaminated water by ultraviolet irradiation, with and emphasis on whirling disease (Myxosoma cerebralis) and its effect on fish. Trans Am Fish Soc 103:541-550

Hoffman GL (1975) Whirling disease (Myxosoma cerebralis) control with ultraviolet irradiation and effect on fish. J Wildl Dis 11:505-507

Hoffman GL (1990) Myxobolus cerebralis, a worldwide cause of salmonid whirling disease. J Aquat Anim Health 2: 30-37

Markiw ME (1989) Portals of entry for salmonid whirling disease in rainbow trout. Dis Aquat Org 6:7-10

Markiw ME (1992a) Salmonid whirling disease. U.S. Department of Interior, Fish and Wildlife Service, Fish and Wildlife Leaflet 17, Washington, DC, p 1-11

Markiw ME (1992b) Experimentally-induced whirling disease. II. Determination of longevity of the infective triactinomyxon stage of Myxobolus cerebralis by vital staining. J Aquat Anim Health 4:44-47

Modin J (1998) Whirling disease in California: a review of its history, distribution, and impacts, 1965-1997. J Aquat Anim Health 10:132-142

Nehring RB, Walker PG (1996) Whirling disease in the wild: the new reality in the intermountain west. Fisheries (Bethesda) 21:28-32

Schaperclaus W (1986) Fish diseases, Vol 2, IV Protoziases. Akademie-Verlag, Berlin, p 665-666

Schechmeister II (1991) Sterilization by ultraviolet irradiation. In: Block SS (ed) Disinfection, sterilization, and preservation, 4th edn. Lea and Febiger, Philadelphia, PA p 553-565

Thoesen JC (1994) Suggested procedures for the detection and identification of certain finfish and shellfish pathogens, 4th rev edn, Ver 1. Fish Health Section, American Fish Society, Bethesda

Vincent ER (1996) Whirling disease and wild trout: the Montana experience. Fisheries (Bethesda) 21:32-34

Wagner E (1998) TAM vital staining: effect of sodium hypochlorite on viability. The Ichthyogram 9(4):4-5

Wolf K (1986) Salmonid whirling disease: status in the United States, 1985. J Wildl Dis 22:295-299

Wolf K, Markiw ME (1984) Biology contravenes taxonomy in the Myxozoa: new discoveries show alternation of invertebrate and vertebrate hosts. Science 225:1449-1452

Submitted: February 15, 2000; Accepted: May 8, 2000

Proofs received from author(s): July 11, 2000 